\title{
Correction to: Fostamatinib: A Review in Chronic Immune Thrombocytopenia
}

\author{
Julia Paik $^{1}$
}

Published online: 26 May 2021

C) Springer Nature Switzerland AG 2021

\section{Correction to: Drugs \\ https://doi.org/10.1007/s40265-021-01524-y}

The copyright statement in the article currently reads incorrectly:

(C) The Author(s), under exclusive licence to Springer Nature Switzerland AG 2021

The correct copyright line should read as:

(C) Springer Nature Switzerland AG 2021

The original article has been corrected.

The original article can be found online at https://doi.org/10.1007/ s40265-021-01524-y.

Julia Paik

demail@springer.com

1 Springer Nature, Mairangi Bay, Private Bag 65901, Auckland 0754, New Zealand 